\title{
Aluminum toxicity to tropical montane forest tree seedlings in southern Ecuador: response of biomass and plant morphology to elevated Al concentrations
}

\author{
Agnes Rehmus • Moritz Bigalke • Carlos Valarezo • \\ Julio Mora Castillo • Wolfgang Wilcke
}

Received: 25 November 2013 / Accepted: 28 March 2014 / Published online: 6 June 2014

(C) Springer International Publishing Switzerland 2014

\begin{abstract}
Aims In acid tropical forest soils $(\mathrm{pH}<5.5)$ increased mobility of aluminum might limit aboveground productivity. Therefore, we evaluated Al phytotoxicity of three native tree species of tropical montane forests in southern Ecuador.

Methods An hydroponic dose-response experiment was conducted. Seedlings of Cedrela odorata L., Heliocarpus americanus L., and Tabebuia chrysantha (Jacq.) G. Nicholson were treated with 0, 300, 600, 1200 , and $2400 \mu M \mathrm{Al}$ and an organic layer leachate. Dose-response curves were generated for root and shoot morphologic properties to determine effective concentrations (EC).

Results Shoot biomass and healthy leaf area decreased by $44 \%$ to $83 \%$ at $2400 \mu M \mathrm{Al}$, root biomass did not respond (C. odorata), declined by $51 \%$ (H. americanus), or was stimulated at low $\mathrm{Al}$ concentrations of $300 \mu M$ (T. chrysantha). EC10 (i.e. reduction by
\end{abstract}

\footnotetext{
A. Rehmus · M. Bigalke · W. Wilcke $(\bowtie)$

Geographic Institute, University of Bern, Hallerstr. 12,

3012 Bern, Switzerland

e-mail: wolfgang.wilcke@giub.unibe.ch

C. Valarezo

Dirección General de Investigaciones, Universidad Nacional de Loja, Ciudadela Universitaria Guillermo

Falconí, sector La Argelia, Loja, Ecuador

J. M. Castillo

Institute of Silviculture, Technische Universität München

Hans-Carl-von-Carlowitz-Platz 2, 85354 Freising Germany
}

$10 \%)$ values of $\mathrm{Al}$ for total biomass were $315 \mu M$ (C. odorata), $219 \mu M$ (H. americanus), and $368 \mu M$ (T. chrysantha). Helicarpus americanus, a fast growing pioneer tree species, was most sensitive to $\mathrm{Al}$ toxicity. Negative effects were strongest if plants grew in organic layer leachate, indicating limitation of plant growth by nutrient scarcity rather than Al toxicity. Conclusions $\mathrm{Al}$ toxicity occurred at $\mathrm{Al}$ concentrations far above those in native organic layer leachate.

Keywords Aluminum toxicity - Tropical forest tree seedlings · Dose-response curves · Organic layer leachate

\section{Introduction}

Aluminum phytotoxicity is known to occur in acid soils (Alleoni et al. 2010; Delhaize and Ryan 1995; Kochian et al. 2004; Schaedle et al. 1989) and is discussed to be one of the major reasons for limited aboveground biomass productivity and low nutrientcycling rates in tropical montane forests (Bruijnzeel 2001; Bruijnzeel and Veneklaas 1998; Hafkenscheid 2000; Leuschner et al. 2007). At soil pH values < 5.5, $\mathrm{Al}$ is plant-available and phytotoxic as $\mathrm{Al}^{3+}$, $\mathrm{AlOH}^{2+}$, or $\mathrm{AlOH}_{2}^{+}$and in various inorganic complexes (Kabata-Pendias and Pendias 2001; Macdonald and Martin 1988). For economic reasons, many studies on Al toxicity have been conducted on crop plants (Kochian et al. 2004; Ryan et al. 2011) and tree species 
used for afforestations (Kinraide 2003; Schaedle et al. 1989). However, only few tropical forest tree species have been tested for their susceptibility to Al toxicity (Cuenca et al. 1990; Watanabe et al. 1998).

Negative effects of high $\mathrm{Al}$ availability include, for instance, inhibition of water and nutrient uptake and plant growth, at which particularly root biomass production is negatively affected (Delhaize et al. 2012; Kochian 1995; Rout et al. 2001; Schaedle et al. 1989; Thornton et al. 1987). Inhibition of root elongation is suggested to be a result of $\mathrm{Al}$ stress to the root meristem (Ryan et al. 1993). Additionally, under limiting conditions such as root damage or nutrient stress, the plants assign carbohydrates to roots rather than to plant shoots (Harris 1992; Leuschner et al. 2007). Furthermore, exudation of chelating compounds to counteract $\mathrm{Al}$ toxicity is energy consuming and happens at the cost of shoot growth (Cuenca et al. 1990). In contrast to these findings, enhancement of root growth (Hajiboland et al. 2013) or plant growth on the whole (Watanabe et al. 1998) has been reported for some tree species at low to moderate $\mathrm{Al}$ concentrations in soil solution.

At our study site in southern Ecuador, a wide distribution of Al-accumulating plant species has been observed (Homeier 2008), which according to Chenery (1948) have Al concentrations $>1000 \mathrm{mg}$ $\mathrm{kg}^{-1}$ in leaves. Predominantly, the $\mathrm{Al}$ accumulators appertain to the families Rubiaceae and Melastomataceae (Homeier 2008). Aluminum accumulation is usually interpreted as adaptation to high plantavailable Al concentrations (Jansen et al. 2002) and thus Al toxicity.

Processes that increase soil acidification in Ecuadorian montane rain forest, for example fire-derived acid deposition (Boy et al. 2008) and nitrogen input in the form of $\mathrm{NH}_{4}^{+}$(Galloway et al. 2004; Wilcke et al. 2013), might increase $\mathrm{Al}$ availability in the future. The increased Al availability may expose native tree species to a greater risk of $\mathrm{Al}$ stress. It can furthermore be expected that the fast growing short-lived pioneer tree species are more susceptible to Al toxicity than the more slowly growing long-lived pioneer tree species.

Currently the $\mathrm{pH}$ value in the leachate solution below the thick organic layers of the Ecuadorian montane rain forest ranges between 4.6 and 5.2, below the critical value of 5.5 for $\mathrm{Al}$ mobilization. Total $\mathrm{Al}$ concentrations in these solutions are low $(<60 \mu M)$ and $>97 \%$ of $\mathrm{Al}$ in the leachate occurs in nontoxic organo-complexes (Wilcke et al. 2001; Wullaert et al. 2013).

Common and economically important tree species in the montane rain forests of southern Ecuador are Cedrela sp (Meliaceae) and Tabebuia chrysantha (Jacq.) G. Nicholson (Bignoniaceae), which are longlived pioneers with slow growth rates (Homeier 2008). They belong to the mid-successional tree species and are typically present in primary old-growth forests (Mosandl and Günter 2008). A representative of earlysuccessional species is Heliocarpus americanus L. (Tiliaceae), a light demanding fast-growing shortlived pioneer tree (Homeier 2008). These three tree species are not $\mathrm{Al}$ accumulators.

In order to test $\mathrm{Al}$ toxicity to non-accumulating tropical montane rain forest trees in southern Ecuador, a hydroponic experiment with seedlings of $C$. odorata, H. americanus, and T. chrysantha was conducted. Our objectives were to:

1. investigate the response of biomass and morphology of native tree species to Al stress,

2. estimate the sensitivity of the seedlings of native tree species to Al toxicity using dose-response curves, thereby assessing whether fast-growing pioneer tree species or old-growth forest tree species are more susceptible to Al toxicity and

3 . compare growth of tree seedlings under nutrientoptimized conditions to growth in native organic layer leachate.

We hypothesize that:

1. Native tree species in the tropical montane rain forest in southern Ecuador respond negatively to in-vitro elevated $\mathrm{Al}$ concentrations and root morphological properties are more strongly affected than shoot morphological properties.

2. Highly productive pioneer tree species are more susceptible to Al toxicity than slow-growing tree species.

3. Critical Al concentrations for toxicity in native tree species are above plant-available Al concentrations in organic layer leachate. 


\section{Materials \& methods}

Experimental design

We set up a hydroponic growth experiment with tree seedlings in a greenhouse at the research station San Francisco ( $\left.4^{\circ} 00^{\circ} \mathrm{S}, 79^{\circ} 05^{\circ} \mathrm{W}\right)$, located in the Reserva Biológica San Francisco on the eastern slope of the Cordillera Real, southern Ecuador. Tree seedlings selected for the experiment were $C$. odorata, $H$. americanus, and $T$. chrysantha, aged 7,6 , and 3 months, respectively. These tree species are currently tested as native alternative species for afforestation to replace the locally common exotic Pinus sp. and Eucalyptus sp. (Mosandl and Günter 2008). Tree seedlings were raised in a nursery from seeds collected from the local forest and germinated in a $50 \%$ soil-sand mixture. At the start of the hydroponic experiment, roots were prewashed thoroughly with tap water to remove soil and rinsed with distilled water before placed in

Table 1 Nutrient composition of made organic layer leachate and Hoagland nutrient solution

\begin{tabular}{lcc}
\hline & $\begin{array}{l}\text { organic layer } \\
\text { leachate }\end{array}$ & $\begin{array}{l}\text { Hoagland nutrient } \\
\text { solution }\end{array}$ \\
\hline Macronutrients $(\mu M)$ & & $1934 \pm 29.7$ \\
$\mathrm{~N}$ & $281 \pm 58.5$ & $115 \pm 12.1$ \\
$\mathrm{P}$ & $10.4 \pm 2.8$ & $601 \pm 3.8$ \\
$\mathrm{~K}$ & $258 \pm 56.9$ & $391 \pm 2.7$ \\
$\mathrm{Ca}$ & $36.9 \pm 6.6$ & $102 \pm 0.9$ \\
$\mathrm{Mg}$ & $98.3 \pm 21.7$ & \\
$\mathrm{Micronutrients}(n M)$ & & $857 \pm 15.1$ \\
$\mathrm{Fe}$ & $1486 \pm 572$ & $198 \pm 1.07$ \\
$\mathrm{Mn}$ & $666 \pm 200$ & $90.1 \pm 2.0$ \\
$\mathrm{Ni}$ & $29.6 \pm 5.1$ & $252 \pm 7.3$ \\
$\mathrm{Cu}$ & $122 \pm 10.6$ & $51.9 \pm 0.75$ \\
$\mathrm{Zn}$ & $133 \pm 19.5$ & \\
$\mathrm{Mo}$ & $0.36 \pm 0.21$ & $0-2400$ \\
$\mathrm{TOC}(n M)$ & $2825 \pm 451$ & \\
$\mathrm{Al}(\mu M)$ & $44.0 \pm 11.3$ & \\
\hline
\end{tabular}

Values are means \pm SE of solutions before weekly replacement, except for $\mathrm{Al}$ in nutrient solution where the range of the treatment is given nutrient solution. Before addition of $\mathrm{Al}$, tree seedlings were grown for two weeks in nutrient solution.

One tenth Hoagland solution (Hoagland and Arnon 1950) was used as the basis for the experiments because it resembles the nutrient composition of the organic layer leachate of the study area (Table 1). Nine replicate seedlings per species were treated with 0 , $300,600,1200$, and $2400 \mu M \mathrm{Al}$, which was added as $\mathrm{AlCl}_{3}$ to the nutrient solution. The $\mathrm{pH}$ was adjusted to 4 using $\mathrm{NaOH}$ and $\mathrm{HCl}$. In addition, to simulate plant growth in natural organic layer leachate, one set of replicates of each tree species was treated with an organic layer leachate, without addition of Al. The organic layer leachate used in the experiment was prepared by irrigating a homogenized fresh sample of the whole organic layer from the local forest with distilled water (Table 1). Each tree seedling was treated with 0.5 L culture solution.

Pots were placed at random and positions changed weekly, when culture solutions were replaced and sampled (mixed sample of the nine replicates per species and treatment). Nutrient solutions were aerated for 15 minutes per hour to ensure aerobic conditions at all times. After six weeks, plants were harvested, washed thoroughly with distilled water and leaves, stem, and roots were separated. Leaves were scanned immediately after separation and dried in a drying oven at $55^{\circ} \mathrm{C}$ to constant weight. Roots were

Table 2 Principal component (PC) loadings of plant biomass and morphological properties

\begin{tabular}{lrrr}
\hline & PC1 & \multicolumn{1}{c}{ PC2 } & \multicolumn{1}{c}{ PC3 } \\
\hline healthy leaf area & $\mathbf{0 . 9 1}$ & 0.11 & -0.25 \\
diseased leaf area & -0.03 & 0.39 & $\mathbf{0 . 6 3}$ \\
shoot biomass & $\mathbf{0 . 8 9}$ & 0.36 & -0.16 \\
root biomass & $\mathbf{0 . 8 8}$ & 0.21 & 0.34 \\
root-to-shoot biomass ratio & 0.07 & -0.13 & $\mathbf{0 . 8 8}$ \\
total root length & 0.52 & $\mathbf{0 . 8 2}$ & 0.08 \\
root diameter & 0.46 & $-\mathbf{0 . 7 3}$ & 0.40 \\
root volume & $\mathbf{0 . 8 6}$ & -0.02 & 0.40 \\
root tips & 0.18 & 0.95 & 0.13 \\
root forks & 0.26 & $\mathbf{0 . 9 3}$ & 0.07 \\
explained variance & 0.37 & 0.33 & 0.17 \\
\hline
\end{tabular}

The data was varimax rotated and only PCs with Eigenvalues $>1$ were accepted. Loadings $>0.6$ are bold 
Table 3 Net total plant growth (g, fresh weight), shoot and root biomass (g, dry weight), root-to-shoot biomass ratio, healthy leaf area $\left(\mathrm{cm}^{2}\right)$, deseased leaf area $\left(\%\right.$ of total leaf area), total root length $(\mathrm{cm})$, root diameter $(\mathrm{mm})$, root volume $\left(\mathrm{cm}^{3}\right)$, forks, and tips for C. odorata, H. americanus, T. chrysantha after 7 weeks of treatment with Hoagland nutrient solution containing 0, 300, 600, 1200, and $2400 \mu M \mathrm{Al}$ and organic layer leachate

$\mathrm{Al}$ concentration $(\mu M)$

0
300

$11.3 \pm 1.00 \mathrm{a}$

$14.2 \pm 0.87 \mathrm{a}$

$10.5 \pm 1.20 \mathrm{ab}$

$7.80 \pm 0.57 \mathrm{abc}$

$13.8 \pm 1.02 \mathrm{a}$

$7.10 \pm 1.03 \mathrm{~b}$

H. americanus

T. chrysantha

$8.10 \pm 0.66 \mathrm{ab}$

$9.02 \pm 0.82 \mathrm{a}$
1200
2400 organic layer

leachate

Shoot biomass (g)

C. odorata

H. americanus

T. chrysantha

Root biomass (g)
C. odorata
H. americanus
T. chrysantha

$$
\begin{aligned}
& 1.71 \pm 0.12 \mathrm{a} \\
& 2.11 \pm 0.16 \mathrm{a} \\
& 1.40 \pm 0.10 \mathrm{~b}
\end{aligned}
$$

$1.48 \pm 0.16 \mathrm{ab}$

$1.17 \pm 0.11 \mathrm{bc}$

$1.67 \pm 0.16 \mathrm{a}$

$1.01 \pm 0.14 \mathrm{~b}$

$1.40 \pm 0.10 \mathrm{a}$

$0.87 \pm 0.10 \mathrm{c}$

$7.16 \pm 0.71 \mathrm{bc}$

$6.99 \pm 0.72 \mathrm{~b}$

$5.80 \pm 0.39 \mathrm{c}$

$6.07 \pm 0.48 \mathrm{bc}$

$3.60 \pm 0.78 \mathrm{~b}$

$4.37 \pm 0.40 \mathrm{c}$

$1.07 \pm 0.12 \mathrm{bc}$

$0.96 \pm 0.07 \mathrm{c}$

$0.88 \pm 0.09 \mathrm{~b}$

$0.56 \pm 0.10 \mathrm{~b}$

$0.89 \pm 0.09 \mathrm{bc}$

$0.61 \pm 0.06 \mathrm{c}$

$0.30 \pm 0.04$

$0.31 \pm 0.03$

$0.22 \pm 0.03$

Root-to-shoot biomass ratio
C. odorata
$0.35 \pm 0.02 \mathrm{~b}$
H. americanus
$0.30 \pm 0.02$
T. chrysantha
$0.20 \pm 0.01 b$

$0.45 \pm 0.02 \mathrm{a}$

$0.42 \pm 0.03 \mathrm{ab}$

$0.51 \pm 0.03 \mathrm{a}$

$0.42 \pm 0.02$

$0.40 \pm 0.04$

$0.32 \pm 0.01 \mathrm{a}$

$0.38 \pm 0.02 \mathrm{ab}$

$0.48 \pm 0.08$

$0.38 \pm 0.02 \mathrm{a}$

$0.47 \pm 0.01 \mathrm{a}$

$0.52 \pm 0.07$

$0.39 \pm 0.02 \mathrm{a}$

$0.41 \pm 0.04$

$0.41 \pm 0.06$

$0.32 \pm 0.08$

Healthy leaf area $\left(\mathrm{cm}^{2}\right)$

$0.13 \pm 0.02$

$0.12 \pm 0.01$

$0.06 \pm 0.01$

\section{C. odorata \\ H. americanus}

$1207 \pm 119$ a

$1075 \pm 63 \mathrm{a}$

T. chrysantha

$$
866 \pm 77 \mathrm{a}
$$

$985 \pm 110 \mathrm{ab}$

$924 \pm 59$ a

$848 \pm 88 \mathrm{a}$
$794 \pm 70 \mathrm{~b}$

$605 \pm 98 \mathrm{~b}$

$603 \pm 49 a b$

$$
\begin{aligned}
& 705 \pm 82 \mathrm{~b} \\
& 528 \pm 56 \mathrm{~b} \\
& 548 \pm 50 \mathrm{~b}
\end{aligned}
$$

$597 \pm 45 \mathrm{~b}$

$410 \pm 46 b$
$187 \pm 39 \mathrm{~b}$

Diseased leaf area (\% of total)

C. odorata

H. americanus

T. chrysantha

Total root length $(\mathrm{cm})$
C. odorata
H. americanus
T. chrysantha

Root diameter (mm)
C. odorata
H. americanus

T. chrysantha

$10 \pm 4.0$

$11 \pm 1.2 \mathrm{bc}$

$2.6 \pm 0.24 \mathrm{~b}$

$$
8.2 \pm 2.3
$$$$
12 \pm 1.7
$$

$8.9 \pm 1.2 \mathrm{c}$

$2.9 \pm 0.34 \mathrm{~b}$

$$
12 \pm 1.1 \mathrm{bc}
$$

$6.7 \pm 2.0 \mathrm{ab}$

$$
\begin{gathered}
12 \pm 2.7 \\
18 \pm 2.3 \mathrm{~b} \\
8.3 \pm 1.4 \mathrm{a}
\end{gathered}
$$

$$
12 \pm 3.0
$$

$54 \pm 4.5 \mathrm{a}$

$13 \pm 2.1 \mathrm{a}$

$$
\begin{aligned}
795 & \pm 58 \mathrm{ab} \\
1202 & \pm 93 \mathrm{~b} \\
795 & \pm 72 \mathrm{ab}
\end{aligned}
$$

$$
\begin{aligned}
& 638 \pm 39 b \\
& 840 \pm 139 b \\
& 644 \pm 50 b
\end{aligned}
$$

$$
\begin{gathered}
144 \pm 10 \\
155 \pm 4.9 \\
79 \pm 11
\end{gathered}
$$

$$
11 \pm 1.5
$$

$$
15 \pm 1.3
$$$$
19 \pm 1.7
$$

$1967 \pm 118 \mathrm{a}$

$946 \pm 76 \mathrm{a}$

$737 \pm 31 \mathrm{ab}$

$\begin{array}{ll}0.67 \pm 0.01 \mathrm{~b} & 0.72 \pm 0.02 \mathrm{ab} \\ 0.43 \pm 0.02 \mathrm{~b} & 0.48 \pm 0.03 \mathrm{ab} \\ 0.55 \pm 0.02 \mathrm{a} & 0.56 \pm 0.01 \mathrm{a}\end{array}$

$0.71 \pm 0.02 \mathrm{ab}$

$0.76 \pm 0.02 \mathrm{a}$

$0.51 \pm 0.01$

$0.54 \pm 0.02 \mathrm{a}$

$0.51 \pm 0.03 \mathrm{ab}$

$0.32 \pm 0.01$

$0.48 \pm 0.02 \mathrm{~b}$

$0.54 \pm 0.02 \mathrm{a}$

$0.48 \pm 0.02 \mathrm{~b}$

$0.53 \pm 0.02$

Root volume $\left(\mathrm{cm}^{3}\right)$

C. odorata

H. americanus

\begin{abstract}
$3.83 \pm 0.34$
\end{abstract}
$3.87 \pm 0.46$

$3.11 \pm 0.37$

$3.17 \pm 0.41$

$2.65 \pm 0.42$
$3.24 \pm 0.36$

$2.87 \pm 0.39$
$2.88 \pm 0.23$

$0.86 \pm 0.06$
$1.88 \pm 0.42$
$0.80 \pm 0.08$ 
Table 3 (continued)

\begin{tabular}{|c|c|c|c|c|c|c|}
\hline \multicolumn{7}{|c|}{ Al concentration $(\mu M)$} \\
\hline & 0 & 300 & 600 & 1200 & 2400 & $\begin{array}{l}\text { organic laye } \\
\text { leachate }\end{array}$ \\
\hline \multicolumn{7}{|l|}{ Root forks } \\
\hline T. chrysantha & $1.76 \pm 0.24 \mathrm{ab}$ & $2.32 \pm 0.31 \mathrm{a}$ & $1.80 \pm 0.07 \mathrm{a}$ & $1.80 \pm 0.13 \mathrm{a}$ & $1.19 \pm 0.14 \mathrm{~b}$ & $0.43 \pm 0.07$ \\
\hline C. odorata & $1340 \pm 171 \mathrm{ab}$ & $1527 \pm 235 \mathrm{a}$ & $1011 \pm 114 \mathrm{ab}$ & $847 \pm 115 \mathrm{ab}$ & $722 \pm 77 b$ & $405 \pm 81$ \\
\hline H. americanus & $8505 \pm 784 \mathrm{a}$ & $8801 \pm 1039 \mathrm{a}$ & $4098 \pm 470 \mathrm{~b}$ & $3548 \pm 247 \mathrm{~b}$ & $2532 \pm 488 b$ & $2430 \pm 115$ \\
\hline T. chrysantha & $1956 \pm 175 a$ & $1784 \pm 235 \mathrm{ab}$ & $1275 \pm 96 \mathrm{~b}$ & $1464 \pm 197 \mathrm{ab}$ & $1255 \pm 168 \mathrm{ab}$ & $284 \pm 51$ \\
\hline \multicolumn{7}{|l|}{ Root tips } \\
\hline C. odorata & $459 \pm 43$ & $614 \pm 76$ & $445 \pm 37$ & $519 \pm 48$ & $464 \pm 50$ & $250 \pm 24$ \\
\hline H. americanus & $3466 \pm 224 \mathrm{a}$ & $3114 \pm 275 a$ & $1792 \pm 194 b$ & $1674 \pm 140 b$ & $1467 \pm 231 b$ & $1203 \pm 72$ \\
\hline T. chrysantha & $587 \pm 32$ & $723 \pm 65$ & $575 \pm 43$ & $808 \pm 81$ & $646 \pm 94$ & $202 \pm 28$ \\
\hline
\end{tabular}

Data refer to means of 9 replicates ( 8 replicates for $H$. americanus and T. chrysantha for the treatments with 0 and $2400 \mu M \mathrm{Al}) \pm \mathrm{SE}$ Lower case letters depict significant differences among treatments with Hoagland nutrient solution at $\mathrm{p}<0.05$

stored cool until scanning with a root scanner and dried at $55^{\circ} \mathrm{C}$ to constant weight immediately after scanning. In addition to the dry weight of roots and shoots (stem and leaves), the fresh weight of the total plants before and after the experiment (growth rate) was determined. Of the 162 seedlings in total, only 4 plants died during the experiment (two seedlings of each of $H$. americanus and $T$. chrysantha, i.e. one seedling of each species in each of the 0 and $2400 \mu M$ treatments, respectively) and were removed without replacement. Leaves were scanned at $300 \mathrm{dpi}$ (24 bit) in color with a Canon scanner (CanoScan LiDE 100). Roots were scanned with an Epson Expression 10000 $\mathrm{XL}$ at $600 \mathrm{dpi}$ (8 bit) grey scale. The scanner was equipped with additional lighting system in the lid to avoid distortion by shadows. Analysis of healthy and diseased leaf area, total root length, average root diameter, root volume, root tips, and root forks was carried out with WinRhizo 2009 (Regent Instruments Inc., Canada).

\section{Chemical analysis}

Roots, stems, and leaves were separated and $50 \mathrm{mg}$ plant material were digested in a microwave oven (MLS Ethos, Germany). To ensure dissolution of aluminosilicates a digestion with $1.6 \mathrm{~mL} 69 \% \mathrm{HNO}_{3}$, $0.6 \mathrm{~mL} 30 \% \mathrm{H}_{2} \mathrm{O}_{2}, 0.1 \mathrm{~mL} 48 \% \mathrm{HF}$, and $1 \mathrm{~mL}$ $5 \% \mathrm{H}_{3} \mathrm{BO}_{3}$ was chosen. Aluminum concentrations in digests of plant tissue were determined with ICP-MS
7700X (Agilent Technologies, Germany). Calcium concentrations were determined with AAS Zeenit 700P (Analytik Jena, Germany). Total nitrogen and total organic carbon (TOC) in nutrient solution were analyzed with a Vario TOC Cube (Elementar Analysensysteme, Germany). $\mathrm{NH}_{4}^{+}-\mathrm{N}, \mathrm{NO}_{3}^{-}-\mathrm{N}$, and $\mathrm{PO}_{4}^{3-}-\mathrm{P}$ concentrations in organic layer leachate before and after weekly treatment were analyzed with a Continuous Flow Analyzer (CFA AutoAnalyzer 3 HR, SEAL Analytical, Germany).

Statistical analysis

A Principal Component Analysis (PCA, R, package psych, Revelle 2013) with varimax rotation was applied in order to reduce the number of variables and to extract interrelations among the root and shoot parameters. The PCA was conducted for the three tree species combined and included the variables healthy and diseased leaf area, shoot and root biomass (dry weight), root-to-shoot biomass ratio, total root length, root diameter, root volume, root tips, and root forks. As an important morphological property which is considered indicative of toxicity effects, the root-to-shoot biomass ratio was included in addition to root and shoot biomass (Graham 2001).

Differences among treatments were tested using one-way ANOVA and post-hoc tests. When ANOVA residuals were normally distributed and showed homogeneity of variances, as post-hoc test Fisher's 

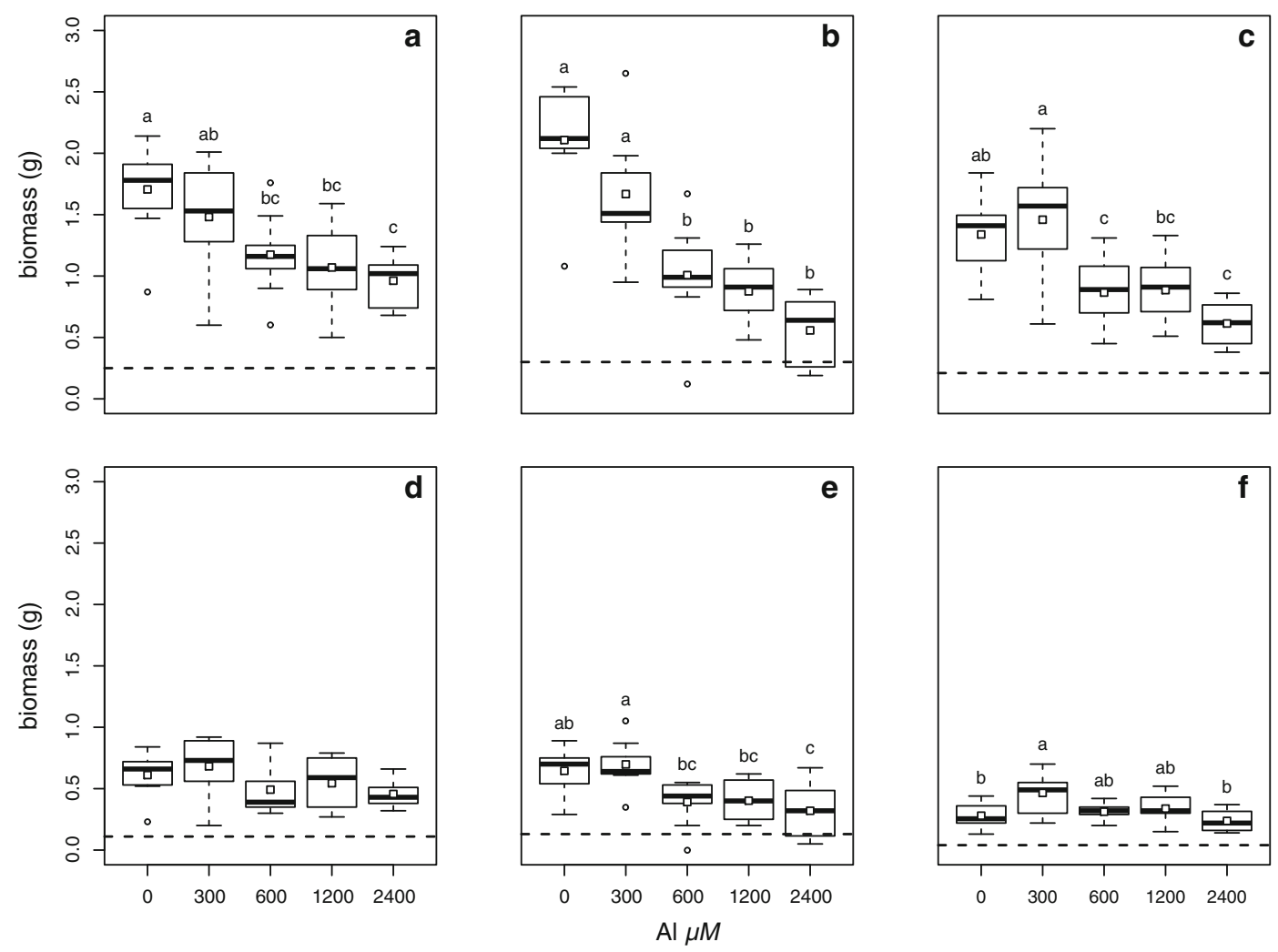

Fig. 1 Boxplots of aboveground (upper row) and root (lower row) biomass for $C$. odorata $(\mathbf{a}, \mathbf{d}), H$. americanus $(\mathbf{b}, \mathbf{e})$, and T. chrysantha (c, f) by treatment $(0,300,600,1200$, and 2400 $\mu M \mathrm{Al})$. Black bars represent the median, whiskers represent the minimum-maximum range of the group data. Group means are given as white squares. Lower case letters above the boxplots depict significant differences among the treatments at $\mathrm{p}$ $<0.05$. The dashed line shows the median in treatment with organic layer leachate least significant difference (LSD) test with Bonferroni correction was chosen for $C$. odorata and Tukey's honest significant difference (HSD) test for unequal $\mathrm{N}$ for $H$. americanus and $T$. chrysantha, because of the loss of two replicates of each of these species. When normal distribution and homogeneity of variances could not be assumed, the Games-Howell test was used. Differences in concentrations of $\mathrm{NH}_{4}^{+}-\mathrm{N}$, $\mathrm{NO}_{3}^{-}-\mathrm{N}$, and $\mathrm{PO}_{4}^{3-}-\mathrm{P}$ in organic layer leachate before and after weekly treatment were tested with the MannWhitney U test. Significance was set at $\mathrm{p}<0.05$ unless otherwise indicated; $* *$ denotes $\mathrm{p}<0.01$ and $* * * \mathrm{p}<0.001$.

Dose-response curves (DRC) were fitted using $\log (\mathrm{x}+1)$-transformed $\mathrm{Al}$ concentrations in nutrient solutions vs. total biomass (dry weight), healthy leaf area, number of root tips, root diameter, root-to-shoot biomass ratio and diseased leaf area (in \% of total leaf area). For the number of root tips a function could only be fitted for $H$. americanus. Fitting failed for root diameter of $T$. chrysantha, for root-to-shoot biomass ratio of $H$. americanus, and for diseased leaf area of C. odorata (Fig. 5).

Effective concentrations (EC) were calculated for 10,20 , and $50 \%$ reduction or enhancement, respectively, compared to control. The treatment with organic layer leachate was considered as a supplemental experiment and was excluded from ANOVA, PCA, and DRC fitting, because strong differences in chemical composition of the solutions complicated a comparison. Statistical analyses were carried out mainly with R 2.13.1 for Windows GUI frontend (R Foundation, Austria). For the Games-Howell test SPSS 19 (IBM Corp., United States) was used. Dose-response curves were fitted with Origin 8.5 for Windows (OriginLab Corporation, USA). 


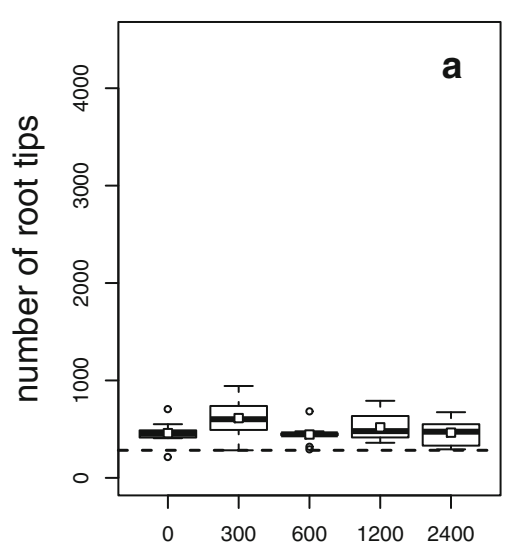

Fig. 2 Boxplots of the number of root tips for $C$. odorata (a), $H$. americanus $(\mathbf{b})$, and $T$. chrysantha (c) by treatment $(0,300$, 600,1200 , and $2400 \mu M \mathrm{Al}$ ). Black bars represent the median, whiskers represent the minimum-maximum range of the group

\section{Results}

Principal component analysis of plant properties

Three principal components (PC) were extracted. The first PC was highly loaded by properties characteristic for biomass (Table 2). The second PC was highly loaded by properties related to root morphology. Root diameter was negatively related to all other root parameters. The third PC was highly loaded by plant properties which are known for their particular
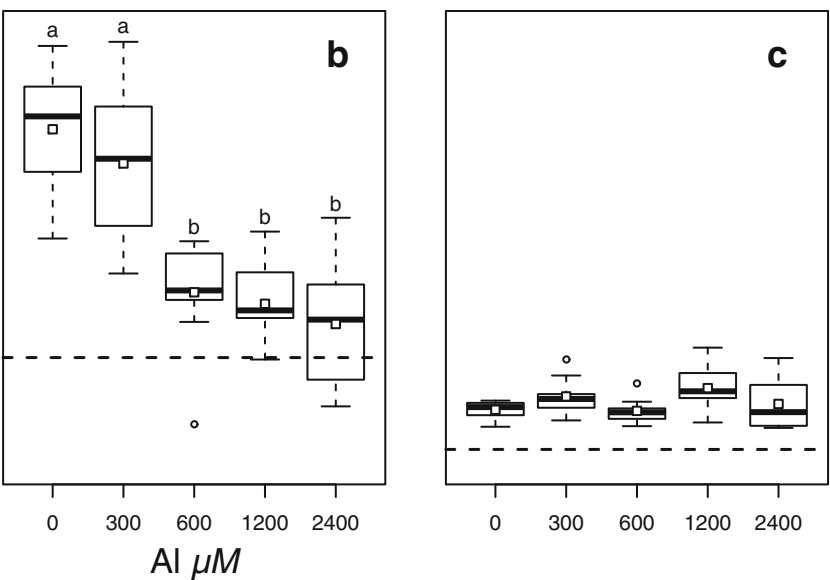

data. Group means are given as white squares. Lower case letters above the boxplots depict significant differences among the treatments at $\mathrm{p}<0.05$. The dashed line shows the median in treatment with organic layer leachate

susceptibility to $\mathrm{Al}$ toxocity, i.e. diseased leaf area and root-to-shoot biomass ratio. All plant properties were significantly affected by increasing Al concentrations with few exceptions (Table 3).

Biomass related plant properties Net total plant growth (difference in fresh weight of the whole plant between start and harvest, not included in the PCA) decreased with increasing $\mathrm{Al}$ concentrations by $49 \%$, $77 \%, 46 \%$ for C. odorata, H. americanus, and T. chrysantha, respectively, and was smallest in the

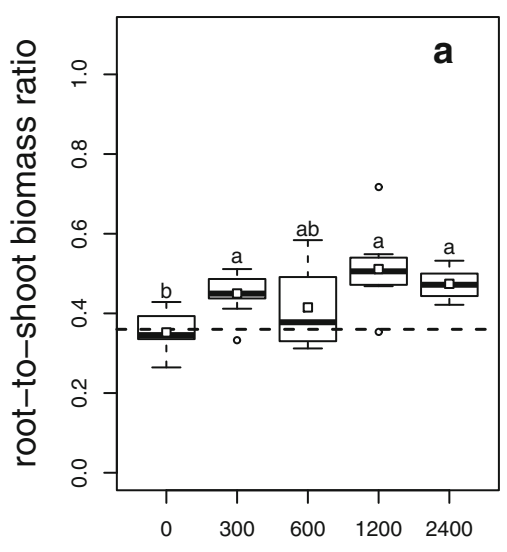

Fig. 3 Boxplots of root-to-shoot biomass ratio for $C$. odorata (a), $H$. americanus $(\mathbf{b})$, and $T$. chrysantha $(\mathbf{c})$ by treatment $(0$, $300,600,1200$, and $2400 \mu M \mathrm{Al})$. Black bars represent the median, whiskers represent the minimum-maximum range of
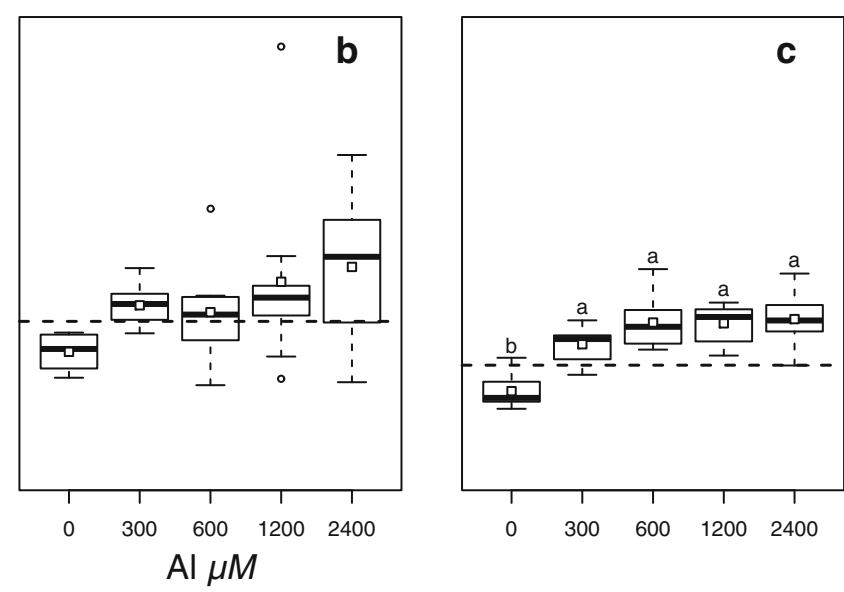

the group data. Group means are given as white squares. Lower case letters above the boxplots depict significant differences among the treatments at $\mathrm{p}<0.05$. The dashed line shows the median in treatment with organic layer leachate 
treatment with organic layer leachate. Shoot biomass decreased as $\mathrm{Al}$ concentrations increased to $2400 \mu \mathrm{M}$ by $44 \%, 73 \%, 56 \%$ for $C$. odorata, $H$. americanus, and $T$. chrysantha, respectively (Fig. 1, Table 3 ). $H$. americanus showed the most distinct decrease of shoot biomass, reflected in the slope of the regressions $(\beta)$ of shoot biomass on $\mathrm{Al}$ concentrations: $\beta=-2.8 \times 10^{-4}, \mathrm{r}=-0.54 * * * ; \beta=-5.8 \times 10^{-4}$, $\mathrm{r}=-0.73 * * * ; \beta=-3.2 \times 10^{-4}, \mathrm{r}=-0.60 * * *$ for C. odorata, H. americanus, and T. chrysantha, respectively.

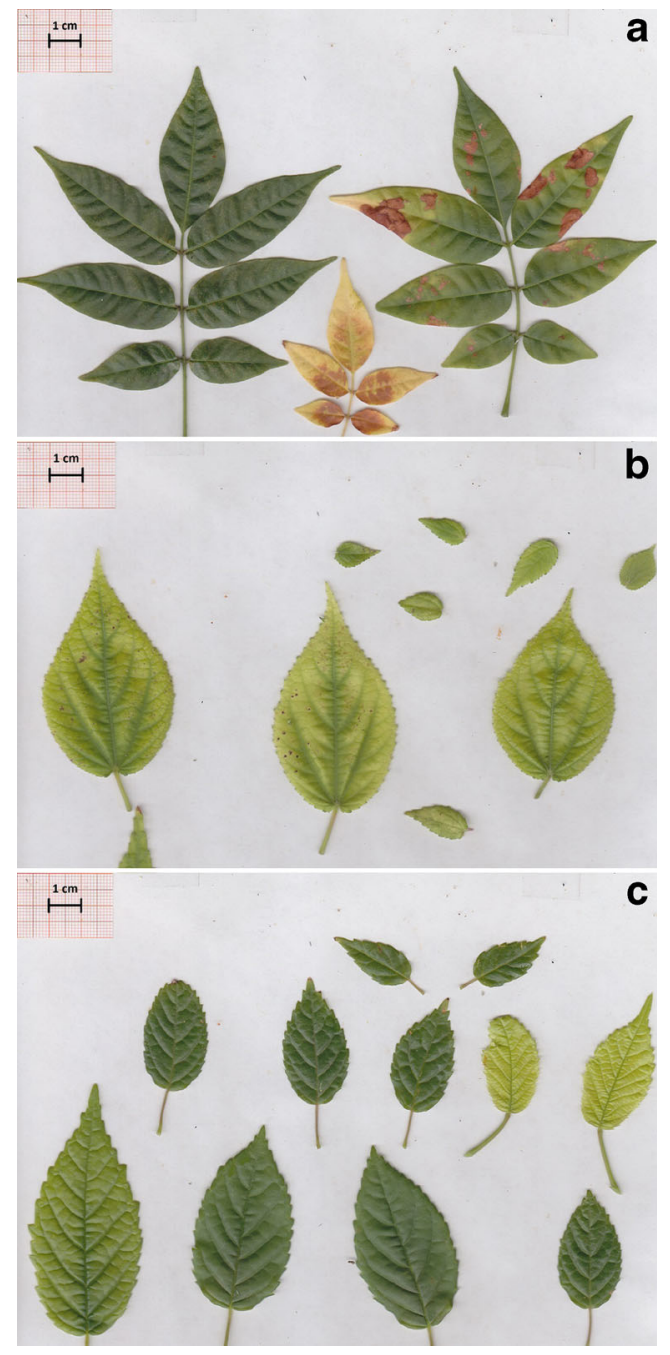

Fig. 4 Diseased leaves of C. odorata (a), H. americanus (b), and $T$. chrysantha (c) in the $2400 \mu M \mathrm{Al}$ treatment. The picture gives a qualitative example of the pale green, yellow, and brown colors of diseased spots
Root biomass was not significantly different among the treatments for $C$. odorata, and decreased significantly by $51 \%$ for $\mathrm{H}$. americanus as $\mathrm{Al}$ concentrations increased (Fig. 1, Table 3). For T. chrysantha root biomass was significantly higher by $68 \%$ at $300 \mu M$ Al compared to control, and decreased to near the control value at $2400 \mu M \mathrm{Al}$. This pattern suggests a stimulation in root biomass production of $T$. chrysantha at low $\mathrm{Al}$ concentrations.

Similar to shoot biomass, healthy leaf area decreased for all tree species with increasing $\mathrm{Al}$ concentration to $2400 \mu M$ by $51 \%, 83 \%, 53 \%$, for

Table 4 EC10, EC20, and EC50 values (in $\mu M$ Al, i.e. effective $\mathrm{Al}$ concentrations, at which 10,20 , and $50 \%$ reduction or enhancement compared to control occurs) for total biomass, healthy leaf area, number of root tips, root diameter, root-toshoot biomass ratio, and diseased leaf area (\% of total) of C. odorata, H. americanus, $T$. chrysantha

\begin{tabular}{|c|c|c|c|}
\hline Parameter & C. odorata & H. americanus & T. chrysantha \\
\hline \multicolumn{4}{|c|}{ Total biomass } \\
\hline EC10 & 315 & 219 & 368 \\
\hline EC20 & 467 & 315 & 461 \\
\hline EC50 & - & 733 & - \\
\hline \multicolumn{4}{|c|}{ Healthy leaf area } \\
\hline EC10 & 150 & 163 & 241 \\
\hline $\mathrm{EC} 20$ & 299 & 350 & 440 \\
\hline EC50 & 2271 & 1093 & 2001 \\
\hline \multicolumn{4}{|c|}{ Number of root tips } \\
\hline EC10 & - & 299 & - \\
\hline $\mathrm{EC} 20$ & - & 359 & - \\
\hline EC50 & - & 657 & - \\
\hline \multicolumn{4}{|c|}{ Root diameter } \\
\hline EC10 & 1736 & 473 & - \\
\hline $\mathrm{EC} 20$ & - & 693 & - \\
\hline EC50 & - & - & - \\
\hline \multicolumn{4}{|c|}{ Root-to-shoot biomass ratio } \\
\hline EC10 & 5.48 & - & 182 \\
\hline $\mathrm{EC} 20$ & 38.3 & - & 212 \\
\hline EC50 & - & - & 281 \\
\hline \multicolumn{4}{|c|}{ Diseased leaf area (\% of total) } \\
\hline EC10 & - & 563 & 229 \\
\hline $\mathrm{EC} 20$ & - & 726 & 311 \\
\hline EC50 & - & 1017 & 475 \\
\hline
\end{tabular}

The hyphen (-) indicates that no EC values could be determined 
C. odorata, H. americanus, and T. chrysantha, respectively (Table 3). Again, a regression of leaf area on $\mathrm{Al}$ concentrations showed the most distinct gradient in decrease of healthy leaf area for $H$. americanus (slope of regression: $\beta=-0.22, \mathrm{r}=-0.57 * * *$; $\beta=-0.35, \mathrm{r}=-0.81 * * * ; \beta=-0.19, \mathrm{r}=-0.64 * * *$ for $C$. odorata, H. americanus, and $T$. chrysantha, respectively).

Root morphology Morphological root properties of $H$. americanus responded most markedly to increasing $\mathrm{Al}$ concentrations (Fig. 2). The number of root tips was not significantly different among the Al treatments for C. odorata and $T$. chrysantha, yet in $H$. americanus it decreased significantly by $58 \%$ at $2400 \mu M$ Al. The root diameter of $C$. odorata and $H$. americanus increased with increasing $\mathrm{Al}$ concentration (by $12 \%$ and $21 \%$ at $2400 \mu M$, respectively). Root diameter of $T$. chrysantha increased by $17 \%$ at $600 \mu \mathrm{M} \mathrm{Al}$ and decreased at further increasing $\mathrm{Al}$ concentrations to similar values like in the control (Table 3).

Indications of Al toxicity There was a significant negative correlation between number of root tips and root diameter for all tree species $(\mathrm{r}=-0.82 * * *)$ and individually for $H$. americanus $\left(\mathrm{r}=-0.93^{* *}\right)$. Rootto-shoot biomass ratio increased significantly with $\mathrm{Al}$ concentration for $C$. odorata and $T$. chrysantha by 34 $\%$ and $95 \%$ at $2400 \mu \mathrm{M} \mathrm{Al}$, resulting from a more pronounced decrease in shoot biomass compared to root biomass (Fig. 3, Table 3).

We observed diseased areas of pale green, yellow, and brown colors (Fig. 4). The diseased leaf area in $\%$ of total leaf area was not significantly different among the $\mathrm{Al}$ treatments for $C$. odorata. However, the fraction of the deseased leaf area increased from $11 \pm 1.2 \%$ and $2.6 \pm 0.24 \%$ in the control treatment to $54 \pm 4.5 \%$ and $13 \pm 2.1 \%$ in the treatment with $2400 \mu M \mathrm{Al}$ in $H$. americanus and T. chrysantha, respectively (Table 3 ).

\section{Dose-response curves}

Best fits for all tree species were achieved for the relationship between $\mathrm{Al}$ concentrations and total biomass and healthy leaf area, respectively. The EC10 values, i.e. the effective concentration of $\mathrm{Al}$ at which the respective plant property was affected by $10 \%$ relative to the control, for all tree species and all fitted plant properties (total biomass, healthy leaf area, number of root tips, root diameter, and diseased leaf area in $\%$ of
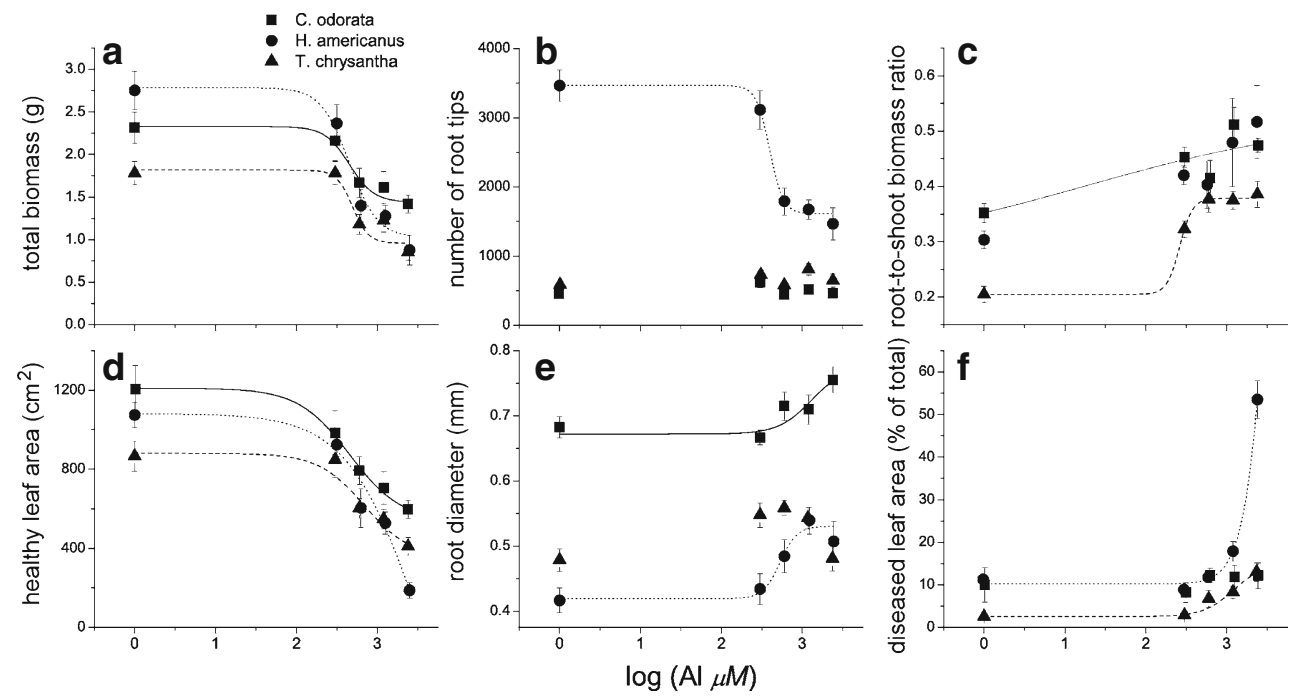

Fig. 5 Dose-response curves of plant properties to Al concentrations for total biomass (dry weight) (a), number of root tips (b), root-to-shoot biomass ratio (c), healthy leaf area $\left(\mathrm{cm}^{2}\right)(\mathbf{d})$, root diameter $(\mathrm{mm})(\mathbf{e})$, and diseased leaf area (\% of total) $(\mathbf{f})$, for C. odorata, H. americanus, and T. chrysantha, respectively. Error bars represent SE of means. Lines are fitted sigmoid growth functions 
total) ranged from 150 to $1736 \mu M$, EC20 from 299 to $726 \mu M$, and EC50 from 475 to $2271 \mu M$. The EC10 values of root-to-shoot biomass ratio ranged from 5.48 to $182 \mu M$, the EC20 values from 38.3 to $212 \mu M$, and the EC50 value of $T$. chrysantha was $281 \mu M$. The root-to-shoot biomass ratio appeared to be the most Al-sensitive plant property, with $C$. odorata responding far more sensitively than $T$. chrysantha (Table 4). With respect to total biomass reduction at increasing $\mathrm{Al}$ concentrations, $H$. americanus responded most sensitively, while $C$. odorata and $T$. chrysantha had similar EC values. Ten and $20 \%$ reduction of healthy leaf area occurred first in $C$. odorata, followed by $H$. americanus and $T$. chrysantha. With respect to root diameter enhancement, $H$. americanus responded more sensitively to increasing $\mathrm{Al}$ concentrations than
C. odorata. Except for the response of diseased leaf area in C. odorata, either H. americanus or C. odorata responded most sensitively to increasing $\mathrm{Al}$ concentrations (Fig. 5, Table 4).

\section{Chemical plant properties}

Aluminum concentrations in roots were significantly higher in the treatments with $\mathrm{Al}$ than in the control treatments (means $\pm \mathrm{SE}$ for C. odorata, H. americanus, and T. chrysantha: $1.42 \pm 0.30,0.00 \pm 0.00$, and $\left.0.35 \pm 0.14 \mathrm{mg} \mathrm{g}^{-1}\right)$. Among the treatments with 300 to $2400 \mu M$ Al no significant differences were observed for $C$. odorata and T. chrysantha (mean Al concentrations \pm SE over all $\mathrm{Al}$ treatments: $14 \pm 0.6$
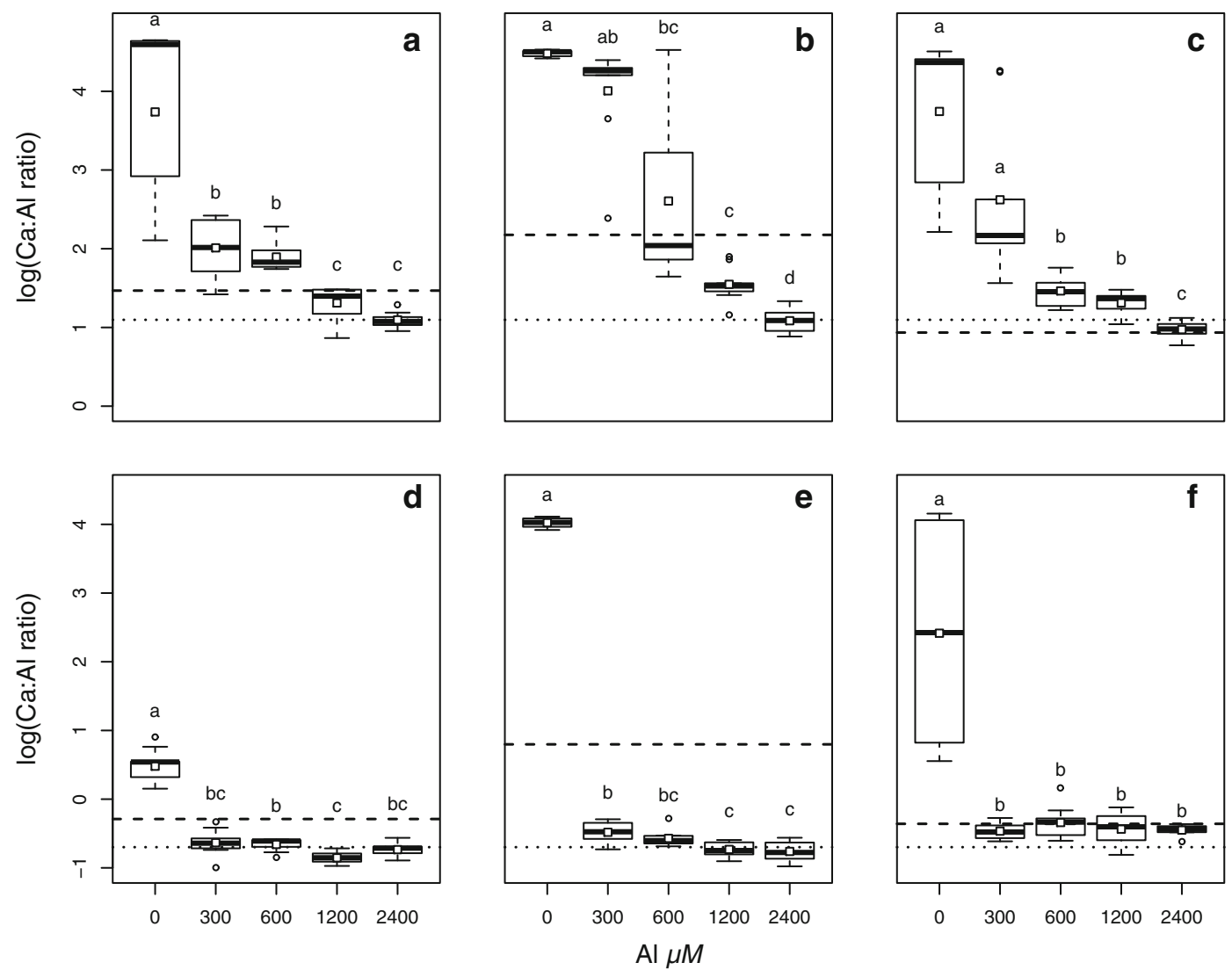

Fig. 6 Boxplots of log-transformed Ca:Al molar ratios in leaf tissue (upper row) and root tissue (lower row) of $C$. odorata (a, d), $H$. americanus $(\mathbf{b}, \mathbf{e})$, and $T$. chrysantha $(\mathbf{c}, \mathbf{f})$ by treatment $(0,300,600,1200$, and $2400 \mu M \mathrm{Al})$. Black bars represent the median, whiskers represent the minimum-maximum range of the group data. Group means are given as white squares.
Lower case letters above the boxplots depict significant differences among the treatments at $\mathrm{p}<0.05$. The dashed line shows the median in treatment with organic layer leachate. The dotted line shows critical $\mathrm{Ca}: \mathrm{Al}$ molar ratios as $\mathrm{Al}$-stress indicators for leaves and roots, respectively (Cronan and Grigal 1995) 
and $6.2 \pm 0.4 \mathrm{mg} \mathrm{g}^{-1}$, respectively). Only for H. americanus, $\mathrm{Al}$ concentrations in roots increased significantly from $9.2 \pm 0.7 \mathrm{mg} \mathrm{g}^{-1}$ at $300 \mu M \mathrm{Al}$ to $19 \pm 0.8 \mathrm{mg} \mathrm{g}^{-1}$ at $2400 \mu M \mathrm{Al}$.

The $\mathrm{Ca}$ concentrations in leaves (mean $\pm \mathrm{SE}$ for C. odorata, H. americanus, and T. chrysantha in control/2400 $\mu M \mathrm{Al}$, respectively: $19 \pm 0.4 / 7.5 \pm 0.6$, $14 \pm 0.5 / 6.7 \pm 0.7,11 \pm 0.5 / 9 \pm 0.8 \mathrm{mg} \mathrm{g}^{-1}$ ) were significantly different among the treatments. In $C$. odorata and $H$. americanus they first decreased from control to treatment with $300 \mu M \mathrm{Al}$, increased at $600 \mu M \mathrm{Al}$ and decreased again with further increasing $\mathrm{Al}$ treatment. In T. chrysantha the mean Ca range was high in leaves treated with $300 \mu \mathrm{M} \mathrm{Al}$ and then decreased in treatments with 600 and $1200 \mu M \mathrm{Al}$ and increased again in the highest $\mathrm{Al}$ treatment.

The Ca:Al molar ratios in leaf tissue decreased significantly from control to treatment with $2400 \mu \mathrm{M} \mathrm{Al}$ in all tree species (Fig. 6). In root tissue, Ca:Al molar ratios of all plants were distinctly higher in control than in all other treatments (Fig. 6).

The TOC concentrations in nutrient solution after weekly treatment increased significantly in the treatments above $300 \mu M \mathrm{Al}$ (Fig. 7).

\section{Organic layer leachate experiment}

The mean of shoot and root biomass (Fig. 1), healthy leaf area, and number of root tips (Fig. 2) for all tree species was lower in the treatment with organic layer leachate than in control and all $\mathrm{Al}$ treatments (Table 3). The mean root diameter of $C$. odorata and $H$. americanus was lower in the organic layer leachate than in control and all Al treatments. The mean of root-to-shoot biomass ratios of the seedlings of all species grown in organic layer leachate was higher than that of the control but lower than the mean of all Al treatments (Table 3). The mean diseased leaf area (in $\%$ of total leaf area) of plants grown in organic layer leachate exceeded that of all other treatments for $T$. chrysantha and the majority of the other treatments for $C$. odorata and H. americanus (Table 3).

Mean Ca concentrations in leaves of plants treated with organic layer leachate were lower than in plants of the control treatment and ranged among the $\mathrm{Al}$ treatments.

The TOC concentrations in organic layer leachate after weekly treatment were with $32.8 \pm 6.4,32.4 \pm 5.4$, and $30.6 \pm 5.5 \mathrm{mg} \mathrm{L}^{-1}$ (mean $\pm \mathrm{SE}$ for $C$. odorata, $H$. americanus, and $T$. chrysantha, respectively) almost 20 times higher than in Hoagland nutrient solution. The concentrations of $\mathrm{NH}_{4}^{+}-\mathrm{N}$ in organic layer leachate decreased during the weekly treatments significantly for $C$. odorata and $H$. americanus from $1.65 \pm 0.3 \mathrm{mg} \mathrm{L}^{-1}$ to $0.6 \pm 0.2$ and $0.4 \pm 0.1 \mathrm{mg}$ $\mathrm{L}^{-1}$, respectively. The concentrations of $\mathrm{NO}_{3}^{-}-\mathrm{N}$ and $\mathrm{PO}_{4}^{3-}-\mathrm{P}$ in organic layer leachate decreased significantly in the course of the experiment, illustrating substantial nutrient depletion by plant uptake for $H$. americanus only (from $1.1 \pm 0.5$ and $0.2 \pm 0.08 \mathrm{mg} \mathrm{L}^{-1}$ to

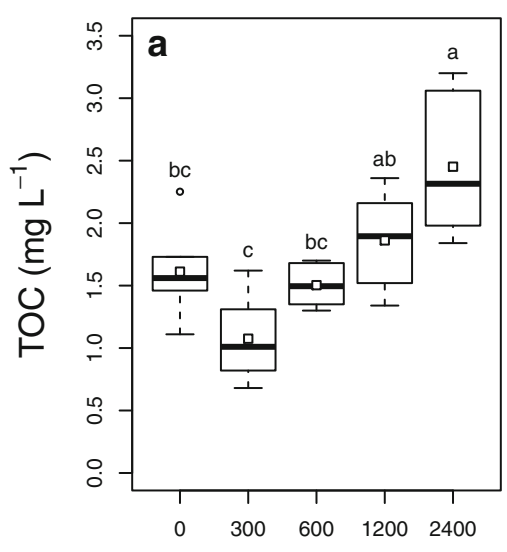

Fig. 7 Boxplots of TOC concentrations $\left(\mathrm{mg} \mathrm{L}^{-1}\right)$ in nutrient solution after weekly treatment of $C$. odorata (a), $H$. americanus (b), and T. chrysantha (c) by treatment $(0,300,600$, 1200 , and $2400 \mu M \mathrm{Al}) . \mathrm{N}=6$, black bars represent the median,
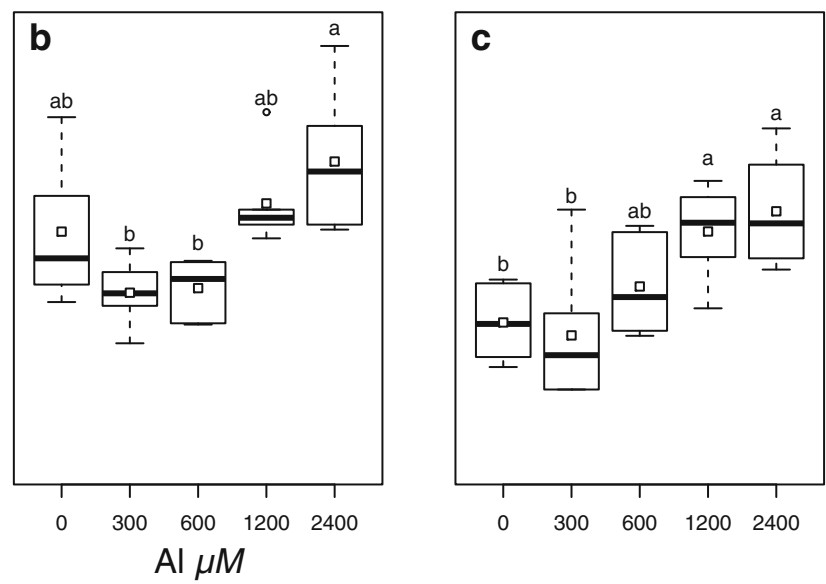

whiskers represent the minimum-maximum range of the group data. Group means are given as white squares. Lower case letters above the boxplots depict significant differences among the treatments at $\mathrm{p}<0.05$ 
$0.1 \pm 0.08$ and $0.03 \pm 0.01 \mathrm{mg} \mathrm{L}^{-1}$, respectively), but not for the other two species.

\section{Discussion}

Aluminum effects on plant biomass and morphology

Several plant properties were negatively affected by increased dissolved $\mathrm{Al}$ concentrations. For most properties, there was no significant difference between control and treatment with $300 \mu M \mathrm{Al}$, as well as among treatments with 600,1200 , and $2400 \mu M \mathrm{Al}$, suggesting that $\mathrm{Al}$ concentrations of $300 \mu M$ must be exceeded to induce significant negative effects on biomass and morphology (Figs. 1 and 2). Significant reduction of plant biomass at $\mathrm{Al}$ concentrations of $250 \mu M$ was reported for red spruce (Picea rubens Sarg.) seedlings by Thornton et al. (1987). The reason for lacking plant responses to low $\mathrm{Al}$ concentrations may be related with efficient defense mechanisms against $\mathrm{Al}$ effects. Some of the mechanisms counteracting $\mathrm{Al}$ stress are release of chelating agents like citrate, malate, and oxalate from the root apex which form non-toxic Al-complexes, or phosphate, that increases $\mathrm{pH}$ of the rhizosphere and precipitates insoluble compounds which cannot be taken up by plants (Brunner and Sperisen 2013; Hafkenscheid 2000; Pellet et al. 1997; Pellet et al. 1995). The increasing TOC concentrations in nutrient solutions of the high Al treatments suggest that the plants responded to $\mathrm{Al}$ stress by the release of chelating compounds (Fig. 7).

Surprisingly, aboveground plant properties (shoot biomass and leaf area) responded more sensitively to Al stress than root properties (Fig. 1 and 2). While shoot biomass decreased by 44 to $73 \%$ compared to control, root biomass either remained unchanged across the treatments $(C$. odorata), declined $(H$. americanus) or was even stimulated al low Al concentrations of $300 \mu M$ and then decreased again at higher Al concentrations ( $T$. chrysantha). This pattern shows that $\mathrm{Al}$ was not interacting directly with the root apex but possibly disturbed nutrient uptake.

The decrease of $\mathrm{Ca}$ concentrations in leaf tissue might result from an inhibited long distance transport of $\mathrm{Ca}$, induced by $\mathrm{Al}$ blocking $\mathrm{Ca}$ channels (Huang et al. 1992; Rengel 1992), which contributes to a negative shoot biomass response to elevated $\mathrm{Al}$ concentrations. In $T$. chrysantha the Ca decrease was less pronounced than in the other two species, indicating less blocking of $\mathrm{Ca}$ transport, which is in line with the less negative response of aboveground biomass production compared to the other two tree species. Compared to other tree species from the same study site, however, even the lowest Ca concentration in leaves was high. Wilcke et al. (2008) reported for Graffenrieda emarginata (Ruiz \& Pav.), an Al-accumulating plant species, Ca concentrations in leaves of $1.2-3.7 \mathrm{mg} \mathrm{g}^{-1}$. In a Ca fertilizing experiment in the Ecuadorian montane forest (Wullaert et al. 2013) trees from control plots had $\mathrm{Ca}$ concentrations in leaves ranging from $0.82 \pm 0.3 \mathrm{mg} \mathrm{g}^{-1}$ (Myrcia sp.nov.) up to $3.25 \pm 1.05 \mathrm{mg} \mathrm{g}^{-1}$ (Alchornea lojaensis Secco). Our results demonstrate that the increasing $\mathrm{Al}$ concentrations in the solution indeed reduced $\mathrm{Ca}$ concentrations in leaves suggesting that reduced $\mathrm{Ca}$ translocation in the plant contributed to decreased biomass production. However, even at the highest $\mathrm{Al}$ concentration in solution, $\mathrm{Ca}$ concentrations in leaves did not drop below those found in the forest.

According to Cronan and Grigal (1995) Ca:Al molar ratios of $<12.5$ and $<0.2$ in leaf and root tissue, respectively, can be used as threshold values indicating $\mathrm{Al}$ stress to forest trees. In our experiment, Ca:Al molar ratios in leaves of all three plant species only approached the threshold value of 12.5 in the highest $\mathrm{Al}$ treatment but did not reach a value below this threshold. However, in the treatment with organic layer leachate, $T$. chrysantha showed a molar $\mathrm{Ca}$ :Al ratio below 12.5 suggesting $\mathrm{Al}$ stress (Fig. 6). In root tissue of $C$. odorata and $H$. americanus the $\mathrm{Ca}: \mathrm{Al}$ molar ratios in all $\mathrm{Al}$ treatments were close to the threshold value for roots. In T. chrysantha $\mathrm{Ca}: \mathrm{Al}$ molar ratios in roots were in all treatments above the threshold. Wullaert et al. (2013) reported Ca:Al molar ratios in leaves of tree species native to the Ecuadorian montane forest, ranging from $0.31 \pm 0.07$ in the $\mathrm{Al}$ accumulating Graffenrieda emarginata (Ruiz \& Pav.) to 71 in Hieronyma fendleri Briq. We attribute the high $\mathrm{Ca}: \mathrm{Al}$ molar ratios to the growth of the seedlings in a particularly Ca-rich substrate in the tree nursery.

Root-to-shoot biomass ratios increased (Fig. 3), contrasting some results in the literature. Thornton et al. (1987) found decreasing root-to-shoot ratios for red spruce seedlings, treated with $\mathrm{Al}$ concentrations as high as $2000 \mu M$. Other studies, however, are more consistent with our findings. Graham (2001) reported 
a negative effect of $1000 \mu M \mathrm{Al}$ on peach seedlings (Prunus persica (L.) Batsch) in sand culture, reducing number and length of plant lateral shoots, total shoot growth, leaf number, and leaf area, but not root, stem, or leaf dry weight. Kidd and Proctor (2000) investigated the Al tolerance of birch populations (Betula pendula Roth) from different ecological sites in a culture solution experiment. In some populations Kidd and Proctor (2000) discovered an enhancement in plant growth at $74-185 \mu M \mathrm{Al}$, followed by growth inhibition at $\mathrm{Al}$ concentrations $>370 \mu \mathrm{M}$. Growth of an Al-sensitive population from a calcareous soil was inhibited at all $\mathrm{Al}$ concentrations in solution $(74-1300 \mu M)$. In contrast, growth of Al-tolerant populations increased with increasing $\mathrm{Al}$ concentrations up to $926 \mu M$ in solution.

Furthermore, a recent study by Hajiboland et al. (2013) revealed stimulation of root growth in a tea plant (Camellia sinensis (L.) Kuntze) at $300 \mu M$ Al. Beneficial effects in culture solution for both, root and shoot biomass, were found for pine (Pinus radiata D.Don and eucalypt (Eucalyptus mannifera Mudie subsp. mannifera) seedlings, whereas strongest plant growth of eucalypt occurred at $2222 \mu M \mathrm{Al}$ and of pine at $370 \mu M \mathrm{Al}$ (Huang and Bachelard 1993). The beneficial effects of $\mathrm{Al}$ on plant growth are explained by alleviation of $\mathrm{H}^{+}$toxicity at low $\mathrm{pH}$ values, which is ascribed to promoted $\mathrm{H}^{+}$extrusion and increase of cell membrane electrical polarity (Kinraide 1993). The resulting electrochemical gradient induces a stimulation of nutrient uptake (Osaki et al. 1997).

In our experiment, the number of root tips was unaffected in $C$. odorata and $T$. chrysantha, but reduced by $60 \%$ in $H$. americanus. This pattern is in line with the $\mathrm{Al}$ concentrations in roots, which were not significantly different among the Al treatments for C. odorata and T. chrysantha but increased for $H$. americanus with increasing $\mathrm{Al}$ cocentrations in the nutrient solution. The higher sensitivity of $H$. americanus can be explained by the fact that the number of root tips in the control was 6 to 7 times higher than of the other two species, illustrating a highly dispersed root architecture, which might be particularly vulnerable to $\mathrm{Al}$ stress (Table 3).

\section{Sensitivity to $\mathrm{Al}$ exposure}

Schaedle et al. (1989) classified sensitive species with growth effects at $\mathrm{Al}$ concentrations below $150 \mu \mathrm{M}$, which include honeylocust (Gleditsia triacanthos L.), coffee (Coffea arabica L.), white spruce (Picea glauca Voss), and peach (Prunus persica (L.) Batsch), intermediately sensitive species responding between 150 and $800 \mu M$ Al which include sugar maple (Acer saccharum Marsch.), red (Picea rubens Sarg.) and black spruce (Picea mariana Mill.), European beech (Fagus sylvatica L.) and loblolly pine (Pinus taeda L.), and resistant species which only respond to $\mathrm{Al}$ concentrations above $800 \mu M$. To directly compare the response of our studied tree species with those in the review of Schaedle et al. (1989), we calculated the EC10 values for aboveground biomass, as aboveground biomass was highly susceptible to $\mathrm{Al}$ toxicity. According to the classification by Schaedle et al. (1989) under in-vitro conditions, the light-demanding fast-growing short-lived pioneer species $H$. americanus (EC10 $126 \mu M$ ) can be classified as sensitive species, and the long-lived pioneers $C$. odorata (EC10 $238 \mu M$ ) and $T$. chrysantha (EC10 $376 \mu M)$ as intermediately sensitive species.

Hoagland nutrient solution versus organic layer leachate

Plants grew generally worse and showed more damages when grown in organic layer leachate than in treatments with Hoagland nutrient solution, irrespective of Al concentration. Accordingly, the highly complex matrix of the organic layer leachate, i.e. nutrient scarcity and possibly complexation of essential micronutrients by organic compounds, must pose problems influencing plant growth more than dissolved Al.

Although $\mathrm{pH}$ values in the organic layer leachate were below 5.5, mean total $\mathrm{Al}$ concentrations in solution were low $(<44 \pm 11 \mu M$, Table 1$)$ and $>$ $97 \%$ were generally bound in organo-Al-complexes (Wullaert et al. 2013), which are known to mask and detoxify Al. At present, our results indicate limitation of biomass production of $C$. odorata, H. americanus, and $T$. chrysantha by other factors than $\mathrm{Al}$ phytotoxicity in the organic layer leachate. The most likely reason are the low concentrations of nutrients (Table 1). This explanation would be in line with findings of Homeier et al. (2012), who recently reported limitation of aboveground productivity in the studied area by simultaneous $\mathrm{N}$ and $\mathrm{P}$ scarcity. Accordingly, plant-available $\mathrm{N}$ and $\mathrm{P}$ concentrations in the organic 
layer leachate tended to decrease during the treatment. However, the reduction of $\mathrm{NH}_{4}^{+}-\mathrm{N}$ was only significant for $C$. odorata and $H$. americanus. The reduction of $\mathrm{NO}_{3}^{-}-\mathrm{N}$ and $\mathrm{PO}_{4}^{3-}-\mathrm{P}$ was only significant for $H$. americanus, indicating that either $\mathrm{N}$ and $\mathrm{P}$ uptake is complicated by other factors for $C$. odorata and $H$. americanus or that other nutrients which we did not consider (e.g. B) could also play a role in limitation of aboveground biomass productivity of the tropical montane forests in southern Ecuador.

\section{Conclusions}

1. Aluminum stress caused negative effects on root and shoot morphology of $C$. odorata, H. americanus, and $T$. chrysantha above $150 \mu M$ of dissolved Al. Yet, shoot properties were stronger affected than root properties.

2. The short-lived pioneer $H$. americanus was most sensitive to Al toxicity confirming that highly productive pioneer tree species could be considered as more vulnerable to $\mathrm{Al}$ stress than old-growth forest tree species.

3. Based on the Al concentrations in organic layer leachate which fall below critical Al concentrations detected in our experiment, there are no indications for an important role of Al toxicity at our study site.

Acknowledgments We thank Karoline Klaus, Katharina Kitzinger, Jose Luis Peña Caivinagua, and Orly Mendoza Aguirre for support in set up of the experiment, Rainer Rees Mertins and Bernd Felderer, ETH Zurich, $\mathrm{CH}$, for support with WinRhizo, Nature and Culture International in Loja, EC, for providing the study area and the research station, Ecuadorian authorities for the research permit, and the German Research Foundation (DFG) for funding (FOR 816, Wi 1601/8-2).

\section{References}

Alleoni LRF, Cambri MA, Caires EF, Garbuio FJ (2010) Acidity and aluminum speciation as affected by surface liming in tropical no-till soils. Soil Sci Soc Am J 74:1010-1017

Boy J, Rollenbeck R, Valarezo C, Wilcke W (2008) Amazonian biomass burning-derived acid and nutrient deposition in the north Andean montane forest of Ecuador. Global Biogeochem Cy 22:1-16. doi:10.1029/2007GB003158

Bruijnzeel L, Veneklaas E (1998) Climatic conditions and tropical, montane forest productivity: the fog has not lifted yet. Ecology 79:3-9. doi:10.2307/176859
Bruijnzeel LA (2001) Hydrology of tropical montane cloud forests: a reassessment. Water Resour Res 1:1-18

Brunner I, Sperisen C (2013) Aluminium exclusion and aluminium tolerance in woody plants. Front Plant Sci 4:1-12. doi:10.3389/fpls.2013.00172

Chenery EM (1948) Aluminium in the plant world. Kew Bull 3:173-183

Cronan CS, Grigal DF (1995) Use of calcium: aluminum ratios as indicators of stress in forest ecosystems. J Environ Qual 24:209-226

Cuenca G, Herrera R, Medina E (1990) Aluminium tolerance in trees of a tropical cloud forest. Plant Soil 125:169-175. doi:10.1007/BF00010654

Delhaize E, Ryan PR (1995) Aluminum toxicity and tolerance in plants. Plant Physiol 107:315-321. doi:10.1104/ pp.107.2.315

Delhaize E, Ma J, Ryan P (2012) Transcriptional regulation of aluminium tolerance genes. Trends Plant Sci 17:341-348

Galloway JN, Dentener FJ, Capone DG, Boyer EW, Howarth RW, Seitzinger SP, Asner GP, Cleveland CC, Green PA, Holland EA, Karl DM, Michaels AF, Porter JH, Townsend AR, Vörösmarty CJ (2004) Nitrogen cycles: past, present, and future. Biogeochemistry 70:153-226. doi:10.1007/ s10533-004-0370-0

Graham CJ (2001) The influence of nitrogen source and aluminum on growth and elemental composition of nemaguard peach seedlings. J Plant Nutr 24:423-439. doi:10.1081/ 100104970

Hafkenscheid RL (2000) Hydrology and biogeochemistry of tropical montane rain forests of contrasting stature in the Blue Mountains, Jamaica. Print Partners Ipskamp, Enschede

Hajiboland R, Bahrami Rad S, Barceló J, Poschenrieder C (2013) Mechanisms of aluminum-induced growth stimulation in tea (Camellia sinensis). J Plant Nutr Soil Sci 176:616-625. doi:10.1002/jpln.201200311

Harris RW (1992) Root-shoot ratios. J Arboric 18:39-42

Hoagland D, Arnon D (1950) The water-culture method for growing plants without soil. University of California, Berkeley

Homeier J (2008) The influence of topography on forest structure and regeneration dynamics in an Ecuadorian montane forest. In: Gradstein, SR, Homeier, J, Gansert, D, Homeier, J, Series 2, Universitätsverlag, Göttingen

Homeier J, Hertel D, Camenzind T, Cumbicus NL, Maraun M, Martinson GO, Poma LN, Rillig MC, Sandmann D, Scheu S, Veldkamp E, Wilcke W, Wullaert H, Leuschner C (2012) Tropical Andean forests are highly susceptible to nutrient inputs - rapid effects of experimental $\mathrm{N}$ and $\mathrm{P}$ addition to an Ecuadorian montane forest. Plos One 7:1-10. doi:10.1371/journal.pone.0047128

Huang J, Shaff JE, Grunes DL, Kochian LV (1992) Aluminum effects on calcium fluxes at the root apex of aluminum-tolerant and aluminum-sensitive wheat cultivars. Plant Physiol 98:230-237

Huang J, Bachelard EP (1993) Effects of aluminium on growth and cation uptake in seedlings of Eucalyptus mannifera and Pinus radiata. Plant Soil 149:121-127. doi:10.1007/ BF00010769

Jansen S, Watanabe T, Smets E (2002) Aluminium accumulation in leaves of 127 species in melastomataceae, 
with comments on the order myrtales. Ann Bot 90:53-64. doi:10.1093/aob/mcf142

Kabata-Pendias A, Pendias H (2001) Trace elements in soils and plants, 3rd edn. CRC Press, Boca Raton

Kidd PS, Proctor J (2000) Effects of aluminium on the growth and mineral composition of Netula pendula Roth. J Exp Bot 51:1057-1066. doi:10.1093/jexbot/51.347.1057

Kinraide TB (1993) Aluminum enhancement of plant growth in acid rooting media. a case of reciprocal alleviation of toxicity by two toxic cations. Physiol Plant 88:619-625. doi:10.1111/j.1399-3054.1993.tb01380.x

Kinraide TB (2003) Toxicity factors in acidic forest soils: attempts to evaluate separately the toxic effects of excessive $\mathrm{Al}^{3+}$ and $\mathrm{H}^{+}$and insufficient $\mathrm{Ca}^{2+}$ and $\mathrm{Cg}^{2+}$ upon root elongation. Eur J Soil Sci 54:323-333. doi:10.1046/j.1365-2389.2003.00538.x

Kochian LV (1995) Cellular mechanisms of aluminum toxicity and resistance in plants. Annu Rev Plant Physiol Plant Mol Biol 46:237-260. doi:10.1146/annurev.pp.46. 060195.001321

Kochian LV, Hoekenga OA, Piñeros MA (2004) How do crop plants tolerate acid soils? Mechanisms of aluminum tolerance and phosphorous efficiency. Annu Rev Plant Biol 55:459-493. doi:10.1146/annurev.arplant.55. 031903.141655

Leuschner C, Moser G, Bertsch C, Röderstein M, Hertel D (2007) Large altitudinal increase in tree root/shoot ratio in tropical mountain forests of Ecuador. Basic Appl Ecol 8:219-230. doi:10.1016/j.baae.2006.02.004

Macdonald T, Martin R (1988) Aluminum ion in biological systems. Trends Biochem Sci 13:15-19. doi:10.1016/09680004(88)90012-6

Mosandl R, Günter S (2008) Sustainable management of tropical mountain forests in Ecuador. Biodivers Ecol Ser 2:177193

Osaki M, Watanabe T, Tadano T (1997) Beneficial effect of aluminum on growth of plants adapted to low $\mathrm{pH}$ soils. Soil Sci Plant Nutr 43:551-563. doi:10.1080/00380768. 1997.10414782

Pellet D, Papernik L, Jones D, Darrah P, Grunes D, Kochian L (1997) Involvement of multiple aluminium exclusion mechanisms in aluminium tolerance in wheat. Plant Soil 192:6368. doi:10.1023/A:1004256121772

Pellet DM, Grunes DL, Kochian LV (1995) Organic acid exudation as an aluminum-tolerance mechanism in maize (Zea mays L.) Planta 196:788-795. doi:10.1007/BF00197346
Rengel Z (1992) Role of calcium in aluminium toxicity. New Phytol 121:499-513

Revelle W (2013) psych: procedures for personality and psychological research, Northwestern University, Evanston, Illinois, USA, Version $=1.3 .10$. http://CRAN.R-project. org/package $=$ psych

Rout GR, Samantaray S, Das P (2001) Aluminium toxicity in plants: a review. Agronomie 21:3-21

Ryan PR, Ditomaso JM, Kochian LV (1993) Aluminium toxicity in roots: an investigation of spatial sensitivity and the role of the root cap. J Exp Bot 44:437-446. doi:10.1093/jxb/44.2.437

Ryan PR, Tyerman SD, Sasaki T, Furuichi T, Yamamoto Y, Zhang WH, Delhaize E (2011) The identification of aluminium-resistance genes provides opportunities for enhancing crop production on acid soils. J Exp Bot 62:920. doi: $10.1093 /$ jxb/erq272

Schaedle M, Thornton F, Raynal D, Tepper H (1989) Response of tree seedlings to aluminum. Tree Physiol 5:337356

Thornton F, Schaedle M, Raynal D (1987) Effects of aluminum on red spruce seedlings in solution culture. Environ Exper Bot 27:489-498. doi:10.1016/0098-8472(87)90030-X

Watanabe T, Osaki M, Tadano T (1998) Effects of nitrogen source and aluminum on growth of tropical tree seedlings adapted to low pH soils. Soil Sci Plant Nutr 44:655-666. doi:10.1080/00380768.1998.10414489

Wilcke W, Yasin S, Valarezo C, Zech W (2001) Change in water quality during the passage through a tropical montane rain forest in Ecuador. Biogeochemistry 55:45-72. doi:10.1023/A:1010631407270

Wilcke W, Oelmann Y, Schmitt A, Valarezo C, Zech W, Homeier J (2008) Soil properties and tree growth along an altitudinal transect in Ecuadorian tropical montane forest. J Plant Nutr Soil Sci 171:220-230. doi:10.1002/jpln. 200625210

Wilcke W, Leimer S, Peters T, Emck RRP, Trachte K, Valarezo C, Bendix J (2013) The nitrogen cycle of tropical montane forest in Ecuador turns inorganic under environmental change. Glob Biogeochem Cycle. doi:10.1002/ 2012GB004471

Wullaert H, Bigalke M, Homeier J, Cumbicus N, Valarezo C, Wilcke W (2013) Short-term response of the Ca cycle of a montane forest in Ecuador to low experimental $\mathrm{CaCl}_{2}$ additions. J Plant Nutr Soil Sci:1-12. doi:10.1002/ jpln.201300146 